\title{
Identifying transcription factor and microRNA mediated synergetic regulatory networks in lung cancer
}

\author{
Ramkrishna Mitra', Jingchun Sun ${ }^{1}$, Min Zhao ${ }^{1}$, Zhongming Zhao ${ }^{1,2,3,4^{*}}$ \\ From 12th Annual UT-ORNL-KBRIN Bioinformatics Summit 2013 \\ Buchanan, TN, USA. 22-24 March 2013
}

\section{Background}

It has been demonstrated that, at the network level, the transcriptional regulation by transcription factors (TFs) and post-transcriptional regulation by microRNAs (miRNAs) are tightly coupled. Aberrant expression of these bio-molecules is linked to several diseases, including lung cancer. In this study, we pursued a regulatory networkbased approach mediated by TFs and miRNAs for a comprehensive investigation of gene regulation patterns in lung cancer.

\section{Materials and methods}

We introduced a directional network that corresponds to significantly differentially expressed (DE) miRNAs and genes between lung tumor and matched normal samples. We predicted miRNA targets in genes by parsing TargetScan prediction results. To find the regulation of TF to genes or miRNAs, we explored the TFs and their binding profiles from the TRANSFAC Professional database. TFs are either significantly DE or have target molecules which are significantly enriched in DE subspace. In this approach, a signed edge of the network illustrates potential repression or activation/repression mediated by a miRNA or TF, respectively, to their target molecules.

\section{Results and conclusions}

We obtained a significantly enriched set of TF- miRNA mediated three-node based feed forward loops (FFLs) with signed edges. The edges of the signed three-node FFLs were validated using completely independent data set. The observation of critical miRNAs in the Wnt

\footnotetext{
* Correspondence: zhongming.zhao@vanderbilt.edu

'Department of Biomedical Informatics, Vanderbilt University, Nashville, TN 37232, USA
}

Full list of author information is available at the end of the article signaling pathway, with partial verification from previous studies, demonstrates that our network-based approach is promising for the identification of new and important miRNAs and their regulation in lung cancer.

\section{Acknowledgements}

We would like to thank the members in Bioinformatics and Systems Medicine Laboratory for their valuable discussion in this project. This work was partially supported by National Institutes of Health grants (R01LM011177, P30CA68485, and P50CA095103).

\section{Authors' details}

'Department of Biomedical Informatics, Vanderbilt University, Nashville, TN 37232, USA. ${ }^{2}$ Department of Psychiatry, Vanderbilt University, Nashville, TN 37232, USA. ${ }^{3}$ Department of Cancer Biology, Vanderbilt University, Nashville, TN 37232, USA. ${ }^{4}$ Center for Quantitative Sciences, Vanderbilt University School of Medicine, Nashville, TN 37232, USA.

Published: 22 October 2013

doi:10.1186/1471-2105-14-S17-A14

Cite this article as: Mitra et al:: Identifying transcription factor and microRNA mediated synergetic regulatory networks in lung cancer. $B M C$ Bioinformatics 2013 14(Suppl 17):A14.

Submit your next manuscript to BioMed Central and take full advantage of:

- Convenient online submission

- Thorough peer review

- No space constraints or color figure charges

- Immediate publication on acceptance

- Inclusion in PubMed, CAS, Scopus and Google Scholar

- Research which is freely available for redistribution

\section{Biomed Central}

(c) 2013 Mitra et al; licensee BioMed Central Ltd. This is an Open Access article distributed under the terms of the Creative Commons Attribution License (http://creativecommons.org/licenses/by/2.0), which permits unrestricted use, distribution, and reproduction in any medium, provided the original work is properly cited. 